\title{
On Japanese culture introduction in Japanese teaching
}

\author{
Baoling Zhou \\ Hebei University of Technology, Tianjin, 300401, China
}

Keywords: Japanese; Japanese teaching; Japanese culture; culture introduction

\begin{abstract}
Language and culture have very close relationship. Language is the carrier of culture, and culture can guide language in turn. So, to master a language, it is required to deeply analyze the culture. Japanese is a national language of Japan has dense Japanese culture connotation. When we learn Japanese, we should carefully learn Japanese culture. Thus, Japanese teachers should attach importance to introducing Japanese culture in Japanese teaching. However, Japanese teaching excessively values cultivation and improvement of basic listening, speaking, reading, writing and translation ability, but greatly neglects Japanese culture introduction in teaching. To change such situation, we must practically and properly introduce Japanese culture in Japanese teaching and really improve Japanese teaching quality and level.
\end{abstract}

\section{Introduction}

People learn a language in order to apply it for communication. So, people often pursue proficient language expression and understandability during learning language. Actually, such language study is pure language study, including profound language culture as the support, or else, language study will finally fail without understanding of cultural connotation. So, China and Japan are neighbors and have similar appearance. Many Japanese characters borrow Chinese characters. However, this does not represent Chinese has no difference with Japanese. In fact, there are great differences between Chinese and Japanese, especially in cultural differences. It thus can be seen that we should change traditional teaching methods in Japanese teaching and introduce Japanese culture in Japanese teaching so as to master Japanese better and fast and proficiently communicate in Japanese.

\section{Relationship between language and culture}

There are two aspects of definition perspective for culture: generalized culture and narrow culture. The former refers to material and spiritual results forming through processing nature, including life style and contents such as food, clothes, resident and travelling. The latter refers to the culture at spiritual level, mainly involving social ideology, system and organization. It can be divided into system culture and mental culture. System culture is reflected in interpersonal relationship, while mental culture is reflected in human and themselves. Language is an important carrier of culture. Culture needs to be spread and saved through language. This is because language is accumulated in social culture and has dense social culture atmosphere. It reflects different cultures if different countries and nations. Culture actually restricts language expression in turn. Therefore, language and culture are indispensible and the two promote and develop mutually.

\section{Relationship between Japanese and Japanese culture}

Seeing from the relationship between language and culture in universal sense, Japanese and Japanese culture also have indispensible relationship. Japanese is outward manifestation of Japanese culture and is an important means and effective carrier for people to mutually exchange and communicate. Although Japanese culture has many shadows of Chinese culture, Japanese culture still has many unique places, because China and Japan have great differences. Generally speaking, Japanese reflects unique island culture. It has several outstanding features, including omission of Japanese. In Japanese, in order to consider the feeling of the other party, people often use 
abbreviated expression way. This is one of typical expressions of Japanese national spirit. Another feature is honorific which mainly aims at the older, superior and strangers so that they can feel their respect.

Application of the relationship between language and culture in language teaching will be of more profound significance. In fact, this will involve specific the thinking mode of language culture. When people cognize objective world, it is a process of listening, speaking and thinking, while the thinking process cannot be separated from the thinking tool - language. We can say expression form of any language is the specific manifestation of the unique thinking mode. We must permeate Japanese culture in Japanese teaching, help students use Japanese thinking to learn Japanese, integrate language teaching and culture teaching and make them mutually promote. Otherwise, without Japanese culture, Japanese teaching will become lifeless and lead to Japanese teaching one-sidedness and abstraction. So, we consider introduction of Japanese culture in abstraction teaching has important actual value.

\section{Current situation of Japanese teaching in China}

In current Japanese teaching process, although certain achievements have received, more teaching characteristics excessively value Japanese itself and neglect Japanese culture. To be more specific, current Japanese course setting and class hour distribution have such problem. In Japanese course setting in many schools, Japanese intensive reading class will often be set, and the class hours for intensive reading occupy most class hours. Besides, listening comprehension, spoken language and extensive reading courses are also set for Japanese. But, class hour arrangement for these courses is less than that of intensive reading. Especially, although courses about Japanese culture are involved in Japanese course setting, the weekly class hours are very few and cannot meet the need of Japanese study. Some students even consider Japanese culture course is a complementary course and the appendant of intensive reading course. Thus, their driving force for learning Japanese culture course reduces greatly. Secondly, there is also an outstanding problem in current Japanese teaching, i.e. the teaching mode of intensive reading course is old-fashioned. Japanese teachers stress vocabulary learning and article comprehension and arrange much time in teaching Japanese grammar and repeated practice. They have no time to take into account of Japanese culture behind the vocabulary and grammar. If things go on like this, students' Japanese knowledge will be solid, but they cannot speak fluent Japanese. This is because Japanese teaching neglects Japanese culture introduction so that Japanese teaching and Japanese culture teaching are completely separated and students cannot really improve teaching effect. Besides, qualified Japanese personnel cannot be cultivated.

\section{Important effects of Japanese culture introduction in Japanese teaching}

Japanese teaching also belongs to language teaching, including basic skill training of listening, speaking, reading, writing and translation. Students' learning situations are evaluated according to the five items. Existing Japanese teaching mode can improve five basic skills of Japanese, but without Japanese culture introduction, the five basic skills cannot withstand a single blow. It is very hard to reach skilful learning state. Among the five skills, listening comprehension is the most difficult one. If students do not know the background of Japanese culture, it is very difficult for them to activate cultural background knowledge ands accurately understand the contents what they listen to. Speaking skill cannot be separated from Japanese culture. This is because without Japanese culture, it is hard to fluently speak or it is hared to express what they want. Even, misunderstanding may be caused. Besides, reading, writing and translation cannot be separated from Japanese culture. Otherwise, students can neither understand nor write perfect Japanese articles, let alone convey the meaning of original text due to incomprehension of Japanese thinking mode and expression habits. Japanese culture introduction in Japanese teaching has important value and effect.

Firstly, in Japanese teaching, we should introduce language culture. This is because introduction 
to Japanese culture in Japanese teaching can make Japanese teaching more pure. Although Chinese and Japanese have countless internal ties, their social backgrounds still have large differences. If Japanese culture is not consciously introduced in Japanese teaching, Japanese application problems may be caused and even Japanese original taste and pureness will be lost in Japanese teaching. In addition, language culture introduction will make Japanese teaching more practical. In Japanese teaching process, Japanese teachers consciously introduce Japanese culture, which will avoid teaching stiffness in traditional teaching and can guide students to better know Japanese culture and enhance Japanese teaching practicability and pertinence.

Secondly, in Japanese teaching, we should introduce non-language factors. We all know that language is outward manifestation of thinking mode. The formation of the thinking mode of a country and a nation mainly root in different social historic culture backgrounds. Of course, it is also indispensible from current social culture. Why do Japanese people like to eat sushi and sashimi? These are related to their historical course and geographical conditions. They are the foundation of Japanese formation and also the foundation for us to guide students to learn Japanese with Japanese thinking. After we introduce these non-language factors in Japanese teaching, students can better know Japan's surroundings and psychological status. Thus, teachers can help students better know Japan's culture and Japanese thinking mode and then lay a good foundation for Japanese study. Of course, introduction to these non-language factors can create good Japanese learning atmosphere, for these non-language factors often include Japanese daily living habits. When students lean Japanese, dense Japanese culture atmosphere can be created through displaying relevant Japanese cultural video so as to stimulate students' learning interest, make them learn Japanese actively and form benign interaction atmosphere of teaching benefits teachers as well as students.

\section{Specific countermeasures to introduce Japanese culture in Japanese teaching}

It is necessary and important to introduce Japanese culture in Japanese teaching. Current Japanese teaching status cannot meet era development requirements. So, we must change such teaching status as soon as possible and introduce Japanese culture in Japanese teaching. Thus, we need to thoroughly change Japanese teaching mode.

Firstly, we should start from custom education and change Japanese teaching mode. Many students do not pay enough attention to custom education. The class hours are few, and the teaching way is dull. Thus, students' learning enthusiasm is seriously damaged. Thus, Japanese teachers should consciously cognize the importance of Japanese custom course. Under the situation where teaching hours cannot effectively increase, we can actively change the role positioning in teaching process, form good interaction relationship with students, make teachers become the main tutors of teaching, make students become learning subjects and really make students become the subject and core of Japanese teaching. In Japanese teaching process, teachers can enhance exchange and communication with students and promote smooth exchange among students so that students and teachers can think and rethink in Japanese teaching.

Secondly, we should change intensive reading teaching mode. Traditional intensive reading teaching is grammar-based teaching so that students continuously learn language sentence pattern imitation, study and practice grammar. Although such traditional intensive reading teaching can make students learn many written instructions, once they use Japanese for communication, they may not know which sentence patterns and grammar should be used for communication. Even if they know how to use the sentence patterns and grammar, if they do not know mood and cultural background of the speakers, the communication will become hard to understand and even lead to misunderstanding. So, to change such teaching status, we should make thorough reform. We can use role drill method to stimulate students' learning passion, and make traditional teaching become rich and vivid. When teachers explain Japanese vocabulary, they can fully excavate culture connotation and make students deepen understanding of Japanese vocabulary on the basis of knowing relevant cultural background knowledge, which contributes to them to better remembering and using Japanese vocabulary. Of course, when we improve intensive reading teaching mode, we should start from teaching materials. Intensive reading teaching materials should contain much 
Japanese cultural knowledge and add more role drill. Besides, Japanese teachers should continuously improve their teaching skills, professional knowledge and cultural foundation so as to better introduce Japanese culture in Japanese teaching. Such Japanese teaching can really cultivate qualified or high-quality Japanese talents.

\section{References:}

[1] Deng Renyou, On Japanese culture introduction in tourism Japanese teaching [J]. Journal of Taiyuan Urban Vocational College, 2012(0l)

[2] Hou Yue, Cultural discussion in Japanese teaching [J]. Japanese Study and Research, 2004

[3] Luo Chuanwei, Features of Japanese and its relationship with Japanese culture [J]. Journal of PLA University of Foreign Languages, 1996

[4] Xia Jianxue, Zhao Quanli, Culture introduction in Japanese teaching [J]. Journal of Hotan Teachers College (Chinese comprehensive edition), 2008(07)

[5] Zhang Yan, Exploration of linguistic theoretical basis in Japanese culture. Journal of PLA University of Foreign Languages, 2001(09) 